\title{
EHMTI-0163. Reduced neck and shoulder strength in patients with tension-type headache. A case control study
}

\author{
BK Madsen ${ }^{1 *}$, K Søgaard ${ }^{2}$, LL Andersen ${ }^{3}, J H$ Skotte $^{3}$, RH Jensen ${ }^{1}$ \\ From 4th European Headache and Migraine Trust International Congress: EHMTIC 2014 \\ Copenhagen, Denmark. 18-21 September 2014
}

\section{Background}

Tension-type headache (TTH) is associated with increased muscle tenderness, with an increasing headache frequency and intensity. The potential role of the peripheral muscles in TTH is unclear, and it is unknown if tenderness is related to strength.

\section{Aims}

To compare muscle strength in neck and shoulder in TTH patients and healthy controls, by examining the Maximal Voluntary Isometric Contraction (MVC) during shoulder abduction, neck flexion and extension as well as the extension-flexion strength ratio of the neck.

\section{Methods}

$60 \mathrm{TTH}$ patients and, 30 sex and aged matched healthy controls were included. Inclusion criteria for patients TTH $\geq 8$ days per month. The MVC in neck extensor and flexor muscles were tested with the subject seated upright. MVC in shoulder abduction was tested with the subject lying supine. The MVC tests were performed using a computerized dynamometer.

\section{Results}

Compared to controls TTH patients had a significantly weaker neck extension $(21.49 \pm 10.31 \mathrm{Nm})$ vs. $(17.07 \pm 9.16$ $\mathrm{Nm})(\mathrm{p}=0.02)$ resulting in a significantly lower Extension/ Flexion moment ratio $(\mathrm{p}=0.03)$. TTH-patients also showed a tendency to significantly lower shoulder abduction strength $(44.3 \pm 19.3 \mathrm{Nm})$ vs. $(38.7, \pm 15.9 \mathrm{Nm}$. $)(\mathrm{p}=0.05)$.

\section{Conclusions}

The reduced neck Extension/Flexion ratio due to decreased strength of the neck extensors and the borderline lower shoulder abduction strength, suggests an unbalanced muscle activity in TTH patients.

No conflict of interest.

\section{Authors' details}

'Neurology, Danish Headache Center, Glostrup, Denmark. ${ }^{2}$ Physical Activity and Health in Work Life, Institute of Sports Science and Clinical Biomechanics University of Southern Denmark, Odense, Denmark. ${ }^{3} \mathrm{NRCWE}$, National Research Centre for the Working Environment, Copenhagen, Denmark.

Published: 18 September 2014

doi:10.1186/1129-2377-15-S1-C40

Cite this article as: Madsen et al: EHMTI-0163. Reduced neck and shoulder strength in patients with tension-type headache. A case control study. The Journal of Headache and Pain 2014 15(Suppl 1):C40.

Submit your manuscript to a SpringerOpen ${ }^{\circ}$ journal and benefit from:

- Convenient online submission

- Rigorous peer review

- Immediate publication on acceptance

- Open access: articles freely available online

- High visibility within the field

- Retaining the copyright to your article

Submit your next manuscript at $\gg$ springeropen.com 